Article

\title{
Hydroconversion of Waste Cooking Oil into Bio-Jet Fuel over NiMo/SBUY-MCM-41
}

\author{
Zongwei Zhang ${ }^{1,2}{ }^{\mathbb{D}}$, Qingfa Wang ${ }^{2, *}$ and Xiangwen Zhang ${ }^{2, *}$ \\ 1 Airport Department Civil Aviation University of China, Tianjin 300300, China; zhv116@163.com \\ 2 Key Laboratory of Green Chemical Technology of Ministry of Education, School of Chemical Engineering \\ and Technology, Tianjin University, Tianjin 300072, China \\ * Correspondence: qfwang@tju.edu.cn (Q.W.); zhangxiangwen@tju.edu.cn (X.Z.); \\ Tel./Fax: +86-22-27892340 (Q.W. and X.Z.)
}

Received: 8 April 2019; Accepted: 17 May 2019; Published: 21 May 2019

check for updates

\begin{abstract}
A hierarchical SBUY-MCM-41 catalyst was prepared by sacrificing USY (a microporous molecular sieve) to synthesize the MCM-41 zeolite via a hydrothermal method. The hydroconversion of waste cooking oil into hydrocarbon fuel over a NiMo/SBUY-MCM-41 catalyst was investigated. The micropores of the $\mathrm{Y}$ building units were inherited by the SBUY-MCM-41 zeolite, in which a special hierarchical structure was formed and the accessibility of reactants to the micropore active sites was improved. The hierarchical SBUY-MCM-41 showed high acidity and hydrothermal stability. Compared with mesoporous Al-MCM-41 and microporous USY zeolites, the SBUY-MCM-41-supported NiMo catalyst significantly enhanced the selective cracking of waste cooking oil for the production of jet-fuel-range hydrocarbons (37.3\%), with the highest selectivity for the formation of $\mathrm{C}_{10}-\mathrm{C}_{14}$ hydrocarbons and a satisfactory selectivity for the formation of jet-fuel-range aromatics $(7.6 \%)$, as well as a few cyclic compounds. The improved selectivity is the result of the special hierarchical structure and acid distribution of SBUY-MCM-41. This work provides a new strategy to synthesize a hierarchical catalyst for producing alternative jet fuel from waste cooking oil and vegetable oils.
\end{abstract}

Keywords: waste cooking oil; hydroconversion; bio-jet fuel; MCM-41

\section{Introduction}

The increasing volume of fossil fuels expended and the resulting carbon emissions continue to exacerbate climate change. In light of this, the production of aviation fuel from renewable energy sources has been extensively studied [1-5]. Accordingly, the hydroconversion of plant oils into bio-jet fuel is a promising strategy to reduce the use of fossil fuels. Haldor Topsoe's HydroFlex ${ }^{\mathrm{TM}}$ technology and the UOP (Universal Oil Products Company) Renewable Jet Fuel Process ${ }^{\mathrm{TM}}$ were developed to convert plant oil (jatropha oil, animal fats and oils, palm oil, etc.) into bio-jet fuel in two-step processes. Many researchers have also focused on developing a one-step process to obtain bio-jet fuel from plant oils [6-9]. These processes are important for their potential industrial application. Recently, waste cooking oil (WCO) has emerged as a promising feedstock for biofuel production [10-12] because it is 2-3 times cheaper than plant oils [13]. The deoxygenation mechanism and the selectivity for the formation of jet fuel have been the focus of WCO research $[14,15]$.

Screening hydroconversion catalysts to find those with a high selectivity of jet fuel and suitable hydrocarbon formation from WCO is a critical step. Micro-/mesoporous composite hierarchical zeolite has been considered a promising material for such catalysts because it combines the advantages of microporous zeolite's strong acidity and mesoporous zeolite's suitable pores $[9,14]$. USY zeolite has strong acidity and plentiful micropores and has been widely used as a hydrocracking catalyst. MCM-41 
has been extensively applied in catalysis because of its large pore size, which allows the effective diffusion of macromolecules. However, compared with microporous zeolites, MCM-41 has weak acidity and relatively low hydrothermal stability because of the highly amorphous nature of its pore walls. Consequently, significant research efforts have been dedicated to improving the acidity and hydrothermal stability of MCM-41 [16,17].

In this context, zeolite $Y$ building units were used in this work to assemble an MCM-41 structure with increased acidity and hydrothermal stability. The resulting catalyst composed of $\mathrm{Ni}$ and Mo supported on the composite hierarchical molecular sieve was used in the hydroconversion of WCO into renewable jet fuel. The aim of using these two materials is to leverage both of their advantages (i.e., enhanced diffusion from the mesoporous material and strong acid sites from USY) to carry out the special reaction. For comparison, pure microporous USY zeolites and pure mesoporous acidic MCM-41 zeolites modified by aluminum were also investigated. The reaction pathways over these catalysts are discussed in this paper. The results could provide an economic route for generating bio-jet fuel from renewable resources and give some insight into the practical design of hierarchical zeolites for the catalytic hydrodeoxygenation of WCO.

\section{Results and Discussion}

\subsection{Textural Structures of Zeolites}

Figure 1 shows the X-ray diffraction (XRD) patterns of the zeolites considered in this study. The wide-angle XRD pattern of the SBUY-MCM-41 zeolite (Figure 1b) shows that USY loses its crystal structure and decomposes into secondary building units in an acidic medium. From the low-angle XRD pattern (Figure 1a), two distinct reflections for SBUY-MCM-41 are observed: an intense one at $2.239^{\circ}$ and a weak one at $4.2^{\circ}$, which can be indexed to the (100) and (110) planes, respectively [18]. The characteristic peak for Al-MCM- 41 is only observed at a higher angle of diffraction $\left(2.4^{\circ}\right)$. This indicates that the unit cell structure of SBUY-MCM-41 is larger than that of Al-MCM-41 because the stiffness and space volume of the secondary USY building units of SBUY-MCM-41 are higher than those of the silicate condensation polymer of Al-MCM-41.
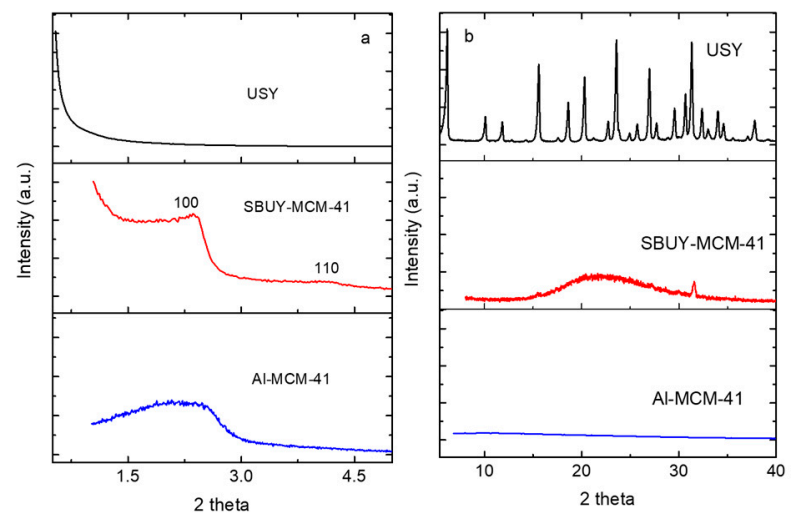

Figure 1. (a) Low-angle and (b) wide-angle XRD patterns of USY, SBUY-MCM-41, and Al-MCM-41.

The porosity properties of SBUY-MCM-41 and Al-MCM-4 are summarized in Table 1. Table 1 shows that the pore diameter of SBUY-MCM- 41 is approximately $2.6 \mathrm{~nm}$, which is smaller than that of Al-MCM-41 $(2.8 \mathrm{~nm})$. The wall thickness of SBUY-MCM-41 $(1.95 \mathrm{~nm})$ is larger than that of Al-MCM-41 $(1.29 \mathrm{~nm})$ owing to the USY secondary building units' larger space volume, which improves the thermal stability of MCM-41 $[18,19]$. Although the mesopore volume of SBUY-MCM-41 is reduced, the micropore volume of SBUY-MCM-41 $\left(0.06 \mathrm{~cm}^{3} \mathrm{~g}^{-1}\right)$ is considerably increased compared with that of Al-MCM-41 $\left(0 \mathrm{~cm}^{3} \mathrm{~g}^{-1}\right)$. The greater micropore volume improves the accessibility of the reactant to the 
active micropore sites and is conducive to the rapid diffusion of the products from the micropores through the mesopores [18].

Table 1. Surface area and pore volume data for Al-MCM-41 and SBUY-MCM-41.

\begin{tabular}{cccccc}
\hline Samples & $\begin{array}{c}\mathbf{S}_{\mathbf{B E T}} \\
\left(\mathbf{m}^{\mathbf{2}} \mathbf{g}^{-\mathbf{1}}\right)\end{array}$ & $\begin{array}{c}\mathbf{V}_{\text {total }} \\
\left(\mathbf{c m}^{\mathbf{3}} \mathbf{g}^{-\mathbf{1}}\right)\end{array}$ & $\begin{array}{c}\text { Unit Cell } \\
(\mathbf{n m})\end{array}$ & $\begin{array}{c}\text { Mesopore Size } \\
(\mathbf{n m})\end{array}$ & $\begin{array}{c}\mathbf{T}_{\text {pore wall }} \\
(\mathbf{n m})\end{array}$ \\
\hline USY & 658 & 0.35 & - & - & - \\
Al-MCM-41 & 885 & 0.83 & 4.09 & 2.8 & 1.29 \\
SBUY-MCM-41 & 820 & 0.64 & 4.55 & 2.6 & 1.95 \\
\hline \multicolumn{5}{c}{$\mathrm{V}_{\text {total }}$ is the total pore volume at $\mathrm{p} / \mathrm{p}_{0}=0.99 . \mathrm{T}_{\text {pore wall }}$ is the thickness of the pore wall. }
\end{tabular}

\subsection{Acidity Distributions of Al-MCM-41 and SBUY-MCM-41}

The acidity properties of the samples were investigated by ammonia temperature programmed desorption $\left(\mathrm{NH}_{3}\right.$-TPD) and Py-FTIR. All the samples presented $\mathrm{NH}_{3}$ desorption peaks in the ranges of $150-350{ }^{\circ} \mathrm{C}, 350-450{ }^{\circ} \mathrm{C}$, and $450-550{ }^{\circ} \mathrm{C}$, which are associated with weak, medium, and strong acidity, respectively. The acidity distribution was calculated according to the amounts of desorbed $\mathrm{NH}_{3}$ and is summarized in Table 2. Table 2 shows that the strong acidity of SBUY-MCM-41 is much higher than that of Al-MCM-41 owing to the contribution of the microstructure of the pore walls in SBUY-MCM-41. The Brønsted/Lewis (B/L) ratio (2.9) of USY is high, indicating that USY is dominated by Brønsted acidity [15]. Compared with USY, SBUY-MCM-41 displays fewer acid sites, especially Brønsted acid sites, because USY was decomposed into secondary building units. The Brønsted acid density of SBUY-MCM-41 is much higher than that of Al-MCM-41, suggesting that the framework $\mathrm{Al}$ (the Brønsted acid site) is introduced more easily and with more stability than Al-MCM-41 [18]. The Lewis acidity of SBUY-MCM-41 is also higher than that of Al-MCM-41 because more non-framework $\mathrm{Al}$ is formed during the preparation process.

Table 2. Acidity properties of USY, SBUY-MCM-41, and Al-MCM-41 $\left(\mu \mathrm{mol} \mathrm{g}{ }^{-1}\right)$.

\begin{tabular}{ccccccc}
\hline Sample & B & L & B/L & $\begin{array}{c}\text { Weak } \\
\text { Acidity }\end{array}$ & $\begin{array}{c}\text { Medium } \\
\text { Acidity }\end{array}$ & $\begin{array}{c}\text { Strong } \\
\text { Acidity }\end{array}$ \\
\hline USY & 1851 & 634 & 2.9 & 158 & 530 & 598 \\
Al-MCM-41 & 158 & 212 & 0.7 & 78 & 184 & 52 \\
SBUY-MCM-41 & 442 & 558 & 0.8 & 71 & 224 & 198 \\
\hline
\end{tabular}

\subsection{Reduction Behavior}

The hydrogen temperature-programmed reduction $\left(\mathrm{H}_{2}-\mathrm{TPR}\right)$ results for the different catalysts are shown in Figure 2. The NiMo/USY catalyst shows principal reduction peaks at $505^{\circ} \mathrm{C}, 572{ }^{\circ} \mathrm{C}$, and $744{ }^{\circ} \mathrm{C}$, which are assigned to the reduction of $\mathrm{Mo}^{6+}$ to $\mathrm{Mo}^{4+}$ in polymeric octahedral Mo species, the reduction of $\mathrm{Ni}^{2+}$ species, and the reduction of tetrahedrally coordinated Mo species in the zeolite cavities, respectively [20,21]. NiMo/SBUY-MCM-41 shows similar reduction behavior, but the peaks are shifted to lower temperatures $\left(481^{\circ} \mathrm{C}, 540{ }^{\circ} \mathrm{C}\right.$, and $\left.739^{\circ} \mathrm{C}\right)$, indicating an increase in the active phase cluster size [22]. This weakens the active metal-support interaction [22,23]. The peaks of $\mathrm{NiMo} / \mathrm{Al}-\mathrm{MCM}-41$ are shifted to much lower temperatures $\left(424{ }^{\circ} \mathrm{C}, 480^{\circ} \mathrm{C}\right.$, and $\left.709^{\circ} \mathrm{C}\right)$. This suggests that there are much weaker interactions between the metal species and the support. Mojet et al. reported that the active metal-support interaction increased as the acidity of the support increased [24]. Table 2 shows that NiMo/Al-MCM-41 has the lowest acidity and that the metal-support interaction is also the weakest, which is in accord with the literatures [24,25]. 


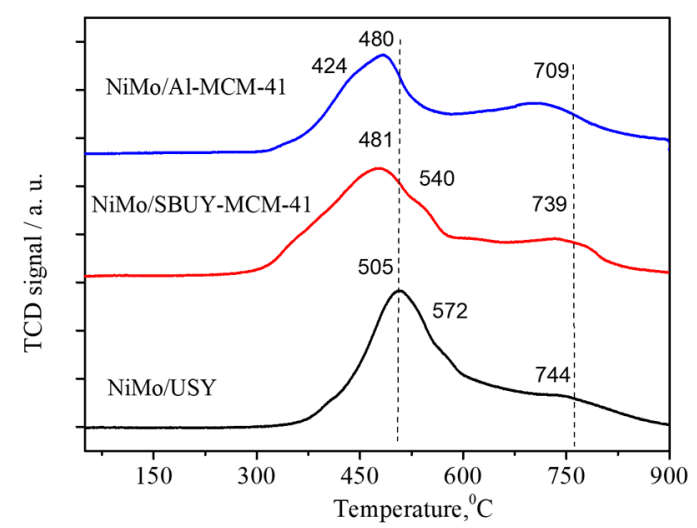

Figure 2. $\mathrm{H}_{2}$-TPR profiles for NiMo catalysts supported on USY and SBUY-MCM-41.

The CO chemisorption data for the different catalysts are shown in Table 3. The amount of CO adsorbed on NiMo/SBUY-MCM-41 and NiMo/Al-MCM-41 increases dramatically compared with that on NiMo/USY because the specific surface areas of the former two species are higher (Table 1). The amount of adsorbed CO on NiMo/SBUY-MCM-41 is also higher than that on NiMo/Al-MCM-41; this is probably because the latter has a smaller active phase cluster size (Figure 2) [23]. This indicates that the SBUY-MCM-41 support provides better dispersion of the active metals- $\mathrm{Ni}$ and $\mathrm{Mo}-$ and affords more active sites than the USY and Al-MCM-41 supports.

Table 3. Adsorbed CO determined by TPD characterization.

\begin{tabular}{cc}
\hline Sample & Adsorbed CO $\left(\mu \mathbf{m o l} \mathbf{g}^{-1}\right)$ \\
\hline NiMo/USY & 1.33 \\
NiMo/Al-MCM-41 & 3.03 \\
NiMo/SBUY-MCM-41 & 3.25 \\
\hline
\end{tabular}

\subsection{Hydrotreatment of WCO}

The hydroconversion of WCO over the three catalysts was also investigated. Approximately 100\% conversions were obtained under the given conditions. Figure 3 a demonstrates that the organic liquid product (OLP) yield for NiMo/SBUY-MCM- 41 reaches $82.1 \%$, which is the highest yield among the three catalysts. This indicates that the use of NiMo/SBUY-MCM-41 does not result in excessive cracking.

There are three reaction pathways for the conversion of triglycerides into alkanes: hydrodeoxygenation (HDO), decarboxylation $\left(\mathrm{DCO}_{2}\right)$, and decarbonylation (DCO). In the reported literature and our previous work $[8,14,15,26]$, the $\mathrm{C}_{17} / \mathrm{C}_{18}$ ratio was used as an index for $\mathrm{DCO}_{\mathrm{x}} / \mathrm{HDO}$ selectivity. Moreover, the $\mathrm{CO}_{2} / \mathrm{CO}$ ratio can be used to distinguish decarboxylation from decarbonylation. For NiMo/USY, the ratio of $\mathrm{C}_{17} / \mathrm{C}_{18}$ hydrocarbons is 1.60 and the $\mathrm{CO}_{2} / \mathrm{CO}$ ratio is 0.17 (Figure $3 b$ ). This indicates that $\mathrm{DCO}_{x}$ reactions, especially the $\mathrm{DCO}$ reaction, are the primary reaction pathways. For the NiMo/Al-MCM- 41 catalyst, the ratio of $\mathrm{C}_{17} / \mathrm{C}_{18}$ hydrocarbons is much lower (1.0). Furthermore, the NiMo/SBUY-MCM-41 catalyst provides a higher ratio of $\mathrm{C}_{17} / \mathrm{C}_{18}$ hydrocarbons (1.1) and the highest $\mathrm{CO}_{2} / \mathrm{CO}$ ratio (1.21), indicating that the $\mathrm{DCO}_{2}$ reaction dominates the hydrodeoxygenation process. It has been reported that high acidity favors $\mathrm{DCO}_{\mathrm{x}}$ reactions $[27,28]$. Table 2 shows that the acid density decreases gradually in the order USY $>$ SBUY-MCM-41 > Al-MCM-41. Therefore, the activity for $\mathrm{DCO}_{\mathrm{x}}$ reactions over these catalysts decreases in the same order (Figure 3). However, the selectivity of $\mathrm{DCO}_{2}$ behaved differently over these catalysts. The as-synthesized hierarchical SBUY-MCM- 41 is more favorable for carrying out hydrodeoxygenation via the $\mathrm{DCO}_{2}$ reaction. 

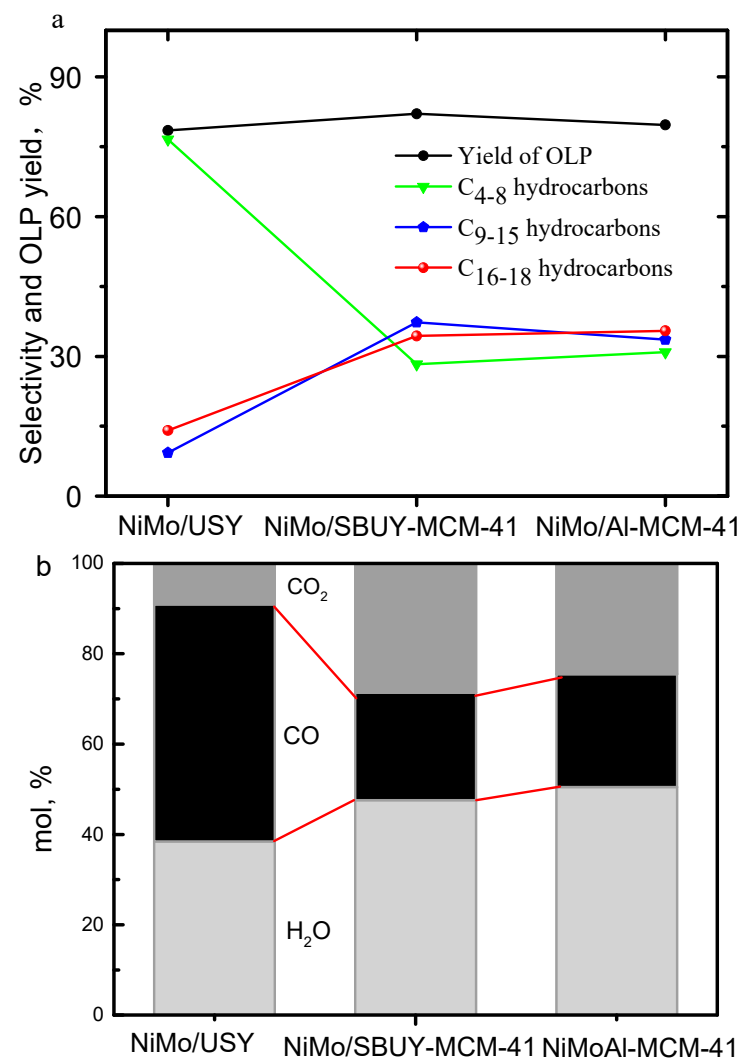

Figure 3. (a) Hydrocarbon distribution and (b) distribution of $\mathrm{H}_{2} \mathrm{O}, \mathrm{CO}$, and $\mathrm{CO}_{2}$ products over different catalysts. Reaction conditions: $380{ }^{\circ} \mathrm{C}, 3 \mathrm{MPa}, 500 \mathrm{~mL} / \mathrm{mL}$.

Different distributions of alkanes were formed via selective hydrocracking over the bifunctional catalysts. $C_{9-15}$ hydrocarbons and $C_{16-18}$ hydrocarbons represent jet fuel and diesel fractions, respectively. The gasoline fraction ( $\mathrm{C}_{4-8}$ hydrocarbons) dominates the products obtained with the NiMo/USY catalyst because of the high values of the medium/strong acidity of the support (Table 2). The Al-MCM-41 zeolite exhibits the lowest values of medium/strong acidity; thus, deep cracking is inhibited, which leads to an increased selectivity for the formation of jet fuel (33.6\%). Although the medium/strong acidity and Brønsted acid values of the SBUY-MCM-41 support are higher than those of Al-MCM-41, the selectivity of SBUY-MCM-41 for the formation of $\mathrm{C}_{9-15}$ hydrocarbons is significantly increased (up to $37.3 \%$ ), and its selectivity for the formation of $\mathrm{C}_{4-8}$ hydrocarbons is further restricted (to $28.3 \%$ ). These results indicate that SBUY-MCM-41 significantly enhances the selective cracking to jet-fuel-range hydrocarbons. This is probably because the hierarchical porous structure improves the accessibility of the reactant to the active micropore sites and increases the diffusion of the products from the micropores through the mesopores.

Figure 4 shows the product distributions of $\mathrm{C}_{9}-\mathrm{C}_{15}$ hydrocarbons (jet-fuel fraction) produced over different catalysts. Of the three catalysts shown in Figure 4a, NiMo/SBUY-MCM-41 has the highest selectivity for the formation of $\mathrm{C}_{10}-\mathrm{C}_{14}$, the optimal jet-fuel fraction. NiMo/USY exhibits the highest selectivity for the formation of aromatic hydrocarbons (29.8\%). The hydrocarbon distributions and aromatic selectivity of NiMo/Al-MCM-41 are similar to those of NiMo/SBUY-MCM-41. However, some cyclic compounds (the ideal jet-fuel fraction) and more useable aromatic content are obtained over the NiMo/SBUY-MCM-41 catalyst. Chen et al. [8] reported that cracking reactions (olefins formed), Diels-Alder cyclization reactions (cycloalkanes formed), and dehydrogenation-aromatization (aromatics formed) occur at Brønsted acid sites, Lewis acid sites, and Brønsted acid sites, respectively. They also concluded that the formation of aromatics is jointly influenced by Brønsted and Lewis acidity [8]. The selectivity for the formation of aromatics and cycloalkanes over the Al-MCM-41 
catalyst is the lowest, and it is probably because it has the fewest Brønsted acid sites $\left(158 \mu \mathrm{mol} \mathrm{g}{ }^{-1}\right)$ and the lowest $\mathrm{B} / \mathrm{L}$ value (0.7). In addition, the density of strong acid sites in Al-MCM-41 is the lowest $\left(52 \mu \mathrm{mol} \mathrm{g}^{-1}\right)$, which is not beneficial to the dealkylation of the higher aromatics into jet fuel [29]. USY exhibits the highest yield of aromatics because it has the highest density of Brønsted acid sites $\left(1851 \mu \mathrm{mol} \mathrm{g}^{-1}\right)$ and the highest B/L value (2.9). The SBUY-MCM-41 catalyst has a higher and more satisfactory selectivity for the formation of aromatics because of its moderate density of Brønsted acid sites $\left(442 \mu \mathrm{mol} \mathrm{g}^{-1}\right)$, suitable B/L value (0.8), and moderate density of strong acid sites $\left(198 \mu \mathrm{mol} \mathrm{g}^{-1}\right)$.
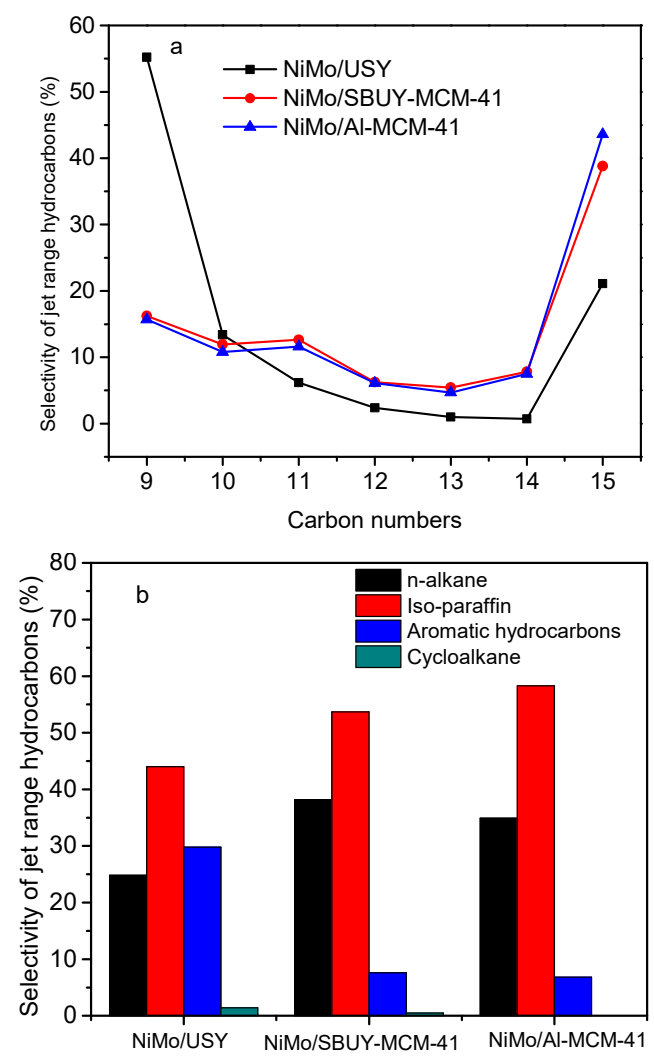

Figure 4. (a) Selectivity for the formation of hydrocarbons with different carbon numbers over different catalysts. (b) Selectivity for the formation of various jet-fuel-range hydrocarbons using different catalysts. Reaction conditions: $380^{\circ} \mathrm{C}, 3 \mathrm{MPa}, 500 \mathrm{~mL} / \mathrm{mL}$.

From the above discussion, the SBUY-MCM-41 structure appears to benefit from both USY and MCM-41. Cracking products escape quickly from MCM-41 with weak acidity and avoid being cracked excessively. Then, the small cracking products form cycloalkanes and aromatics on the dealuminated $\mathrm{Y}$ building units with strong acidity, and the higher cycloalkanes and aromatics compose the jet fuel fraction.

Figure 5 shows the variation in product distribution of the $\mathrm{C}_{9-15}$ hydrocarbons (jet-fuel fraction) vs. time on stream. The iso-/n-paraffin ratio $(\mathrm{i} / \mathrm{n})$ and the selectivity for the formation of aromatics decrease slightly with time because the acid sites become covered by basic nitrogen compounds (such as dimethylamine, which is formed after the deterioration of oil and the condiments added to oil during cooking). 


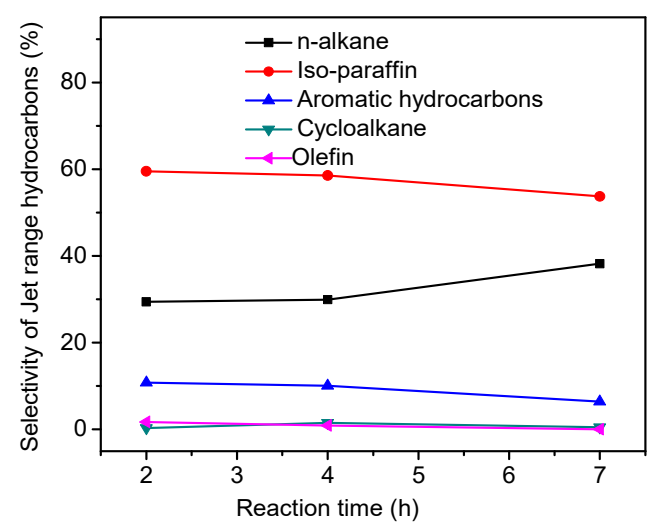

Figure 5. Selectivity for the formation of various jet-fuel-range hydrocarbons in the conversion of WCO over NiMo/SBUY-MCM-41. Reaction conditions: $380{ }^{\circ} \mathrm{C}, 3 \mathrm{MPa}, 500 \mathrm{~mL} / \mathrm{mL}$.

\subsection{Effects of Temperature, Pressure, and Hydrogen-to-Oil Ratio on the Hydrotreatment of WCO}

The effect of temperature on hydrocracking performance is shown in Figure 6. The WCO conversions are $90 \%, 100 \%$, and $100 \%$ at 340,380 , and $400{ }^{\circ} \mathrm{C}$, respectively, and the yields of OLPs are very similar to one another $(82.9 \%, 82.1 \%$, and $80.2 \%)$. The selectivity for the formation of gasoline products dramatically increases with the decrease in diesel and jet-fuel selectivity because the cracking is enhanced at high temperatures. The selectivity for the formation of iso-paraffin decreases because the reaction is exothermic, and the selectivity for the formation of jet-fuel-range aromatics also decreases with increasing temperature. Thus, an optimal temperature of $380^{\circ} \mathrm{C}$ is obtained for jet-fuel selectivity and properties.

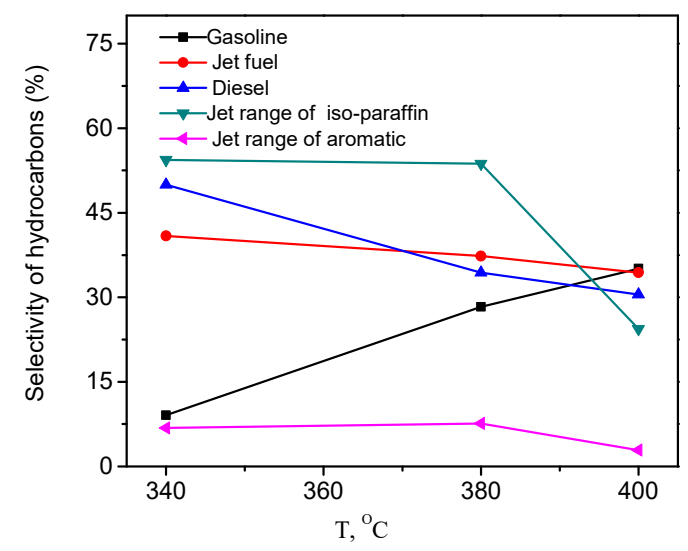

Figure 6. Selectivity for the formation of hydrocarbons using NiMo/SBUY-MCM-41 at different reaction temperatures. Reaction conditions: $3 \mathrm{MPa}$ and $500 \mathrm{~mL} / \mathrm{mL}$.

The influence of pressures (ranging from 2 to $4 \mathrm{MPa}$ ) on the hydroconversion of WCO was also investigated (Figure 7), and 100\% WCO conversions are achieved under these conditions. The yields of OLPs gradually decrease as the pressure increases $(83.9 \%, 82.1 \%$, and $79.2 \%$ at 2,3 , and $4 \mathrm{MPa}$, respectively). Furthermore, as the pressure increases, the selectivity for the formation of gasoline products increases and the selectivity for the formation of diesel decreases. The selectivity for the formation of jet fuel and iso-paraffin varies little with pressure. Low pressure favors the formation of aromatics because it promotes cycloalkane dehydrogenation. 


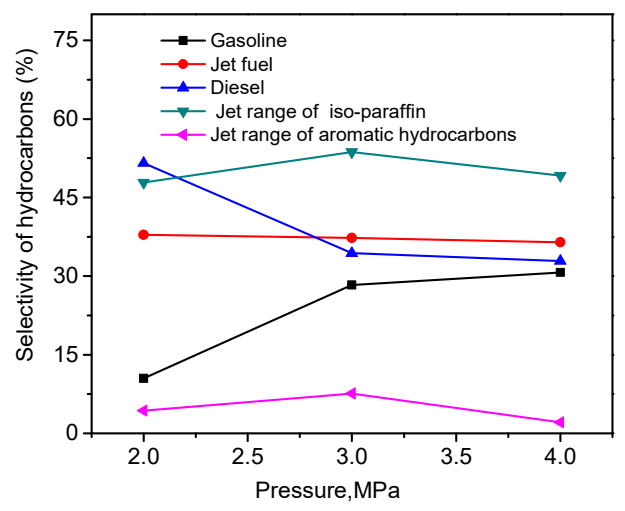

Figure 7. Selectivity for the formation of hydrocarbons using NiMo/SBUY-MCM-41 at different pressures. Reaction conditions: $380{ }^{\circ} \mathrm{C}, 500 \mathrm{~mL} / \mathrm{mL}$.

The effect of the $\mathrm{H}_{2} /$ oil ratio on hydrocracking performance is shown in Figure 8. Approximately $100 \%$ WCO conversion is achieved under these conditions. The yields of OLPs at $\mathrm{H}_{2} /$ oil ratios of 250, 500 , and 750 are $82.5 \%, 82.1 \%$, and $78.0 \%$, respectively. As the $\mathrm{H}_{2} /$ oil ratio increases, the selectivity for the formation of jet fuel and iso-paraffin increases and then decreases, with an optimum value at an $\mathrm{H}_{2} /$ oil ratio of $500 \mathrm{~mL} \mathrm{~mL}^{-1}$. A low $\mathrm{H}_{2} /$ oil ratio favors the formation of aromatics. A likely reason for this is that low $\mathrm{H}_{2} / \mathrm{oil}$ ratios promote the dehydrogenation of alkanes and cycloalkanes.

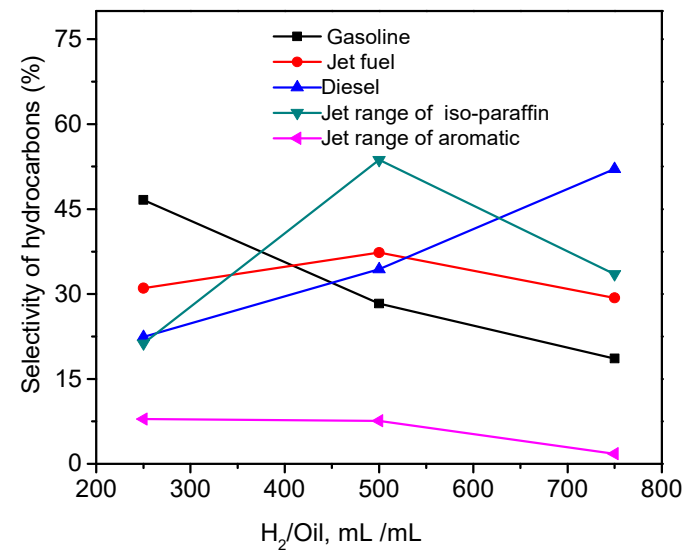

Figure 8. Selectivity for the formation of hydrocarbons using NiMo/SBUY-MCM-41 at different $\mathrm{H}_{2} / \mathrm{Oil}$ ratios. Reaction conditions: $380^{\circ} \mathrm{C}, 3 \mathrm{MPa}$.

\subsection{The Effects of USY Content on the Hydrotreatment of WCO}

Figure 9 shows the variation in the product distribution and jet-fuel composition as the USY content changes. The $\mathrm{Na}_{2} \mathrm{SiO}_{2} \cdot 9 \mathrm{H}_{2} \mathrm{O} / \mathrm{USY}$ mass ratios of $11 \mathrm{NiMo} / \mathrm{SBUY}-\mathrm{MCM}-41$, NiMo/SBUY-MCM-41, and 4 NiMo/SBUY-MCM-41 are 11, 7, and 4. Figure 9 reveals that the selectivity for the formation of jet fuel varies little with the USY content. However, the selectivity for iso-paraffin decreases with the increase in USY content owing to the higher density of strong acid sites [30] from the secondary Y building units in the pore walls. The selectivity for the formation of cycloalkane increases, and the selectivity for the formation of aromatics increases and then decreases as the USY content increases. Thus, the content of USY has little influence on the hydrocarbon distribution, but it affects the hydrocarbon composition significantly. Therefore, the USY content could be used to adjust product properties. 


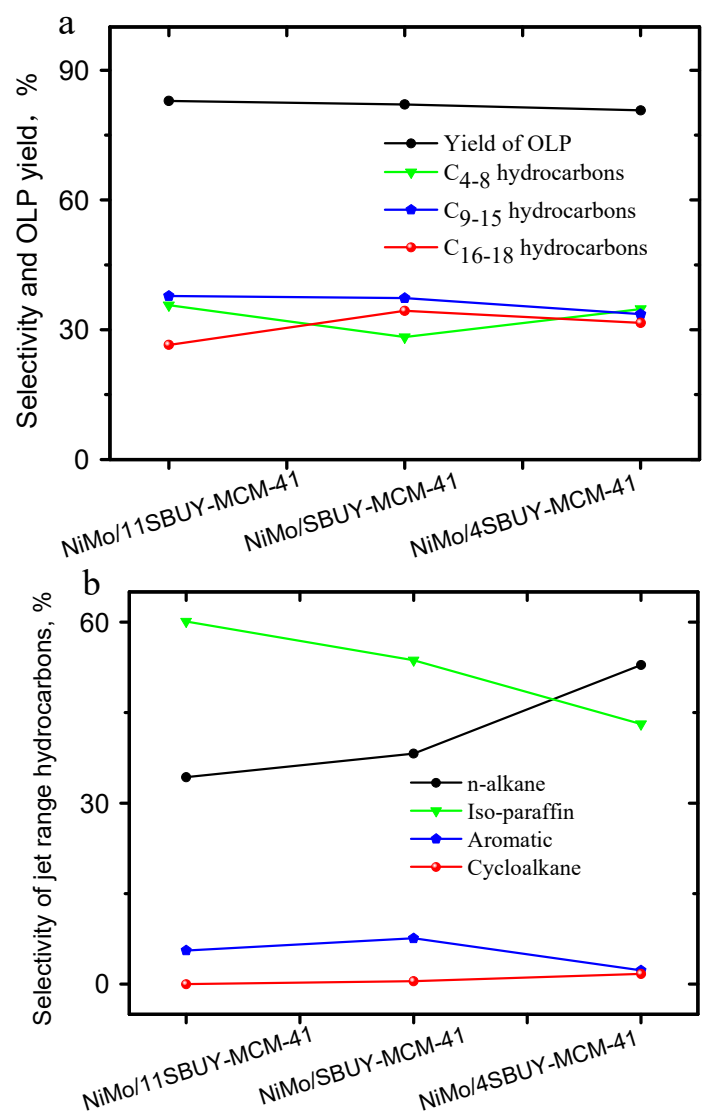

Figure 9. Product selectivity in the hydrotreatment of WCO over NiMo/SBUY-MCM-41. (a) Hydrocarbon distribution and (b) hydrocarbon composition.

\section{Experimental}

\subsection{Materials}

Commercial USY zeolite $\left(\mathrm{Si} / \mathrm{Al}_{\mathrm{XRD}}=4.1, \mathrm{Si} / \mathrm{Al}_{\mathrm{XRF}}=8.8\right)$ was provided by Nankai University Catalyst Co. (Tianjin, China), $\left(\mathrm{NH}_{4}\right)_{6} \mathrm{Mo}_{7} \mathrm{O}_{24}(\geq 99 \mathrm{wt} \%$, J\&K Chemical Ltd., Beijing, China), sodium hydroxide $(\mathrm{NaOH})$, sodium silicate, and cyclohexane were supplied by Tianjin Guangfu Chemical Industry (Tianjin, China). WCO was purchased from Tianjin Bihai Environmental Protection Ltd., Co., (Tianjin, China). The WCO used in this study contains a mixture of spent cooking oil and was mainly gathered from local restaurants, after which it was filtered by a regular sieve to remove the remaining food particles before it was used as feedstock. Table 4 lists the main physical and chemical properties.

Table 4. Chemical and physical properties of waste cooking oil.

\begin{tabular}{cc}
\hline Property & Waste Cooking Oil \\
\hline Acid value $\left(\mathrm{mg} \mathrm{KOH}^{-1}\right)$ & 65.47 \\
Palmitic acid $\left(\mathrm{C}_{16: 0}, \mathrm{wt} \%\right)$ & 25.02 \\
Linoleic acid $\left(\mathrm{C}_{18: 2}, \mathrm{wt} \%\right)$ & 28.85 \\
Oleic acid $\left(\mathrm{C}_{18: 1}, \mathrm{wt} \%\right)$ & 39.69 \\
Stearic acid $\left(\mathrm{C}_{18: 0}, \mathrm{wt} \%\right)$ & 6.27 \\
Other acid $(\mathrm{wt} \%)$ & 0.17 \\
\hline
\end{tabular}

\subsection{Catalyst Preparation}

NiMo/SBUY-MCM-41 preparation: In a typical run [31], the cationic surfactant CTAB (10.934 g) was dissolved in $150 \mathrm{~mL}$ of water containing $25 \mathrm{~mL}$ of $\mathrm{HCl}(10 \mathrm{M})$, and the resulting mixture was added 
to a solution containing $42.64 \mathrm{~g}$ of $\mathrm{Na}_{2} \mathrm{SiO}_{3} \cdot 9 \mathrm{H}_{2} \mathrm{O}$ and $6 \mathrm{~g}$ of USY in $150 \mathrm{~mL}$ of water. The mixture was stirred for $0.5 \mathrm{~h}$, and then the $\mathrm{pH}$ was adjusted to 1.0. The mixture was transferred to an autoclave for further condensation at a hydrothermal crystallization temperature of $120^{\circ} \mathrm{C}$ for one day after stirring at room temperature for $2 \mathrm{~h}$. Next, the catalyst was dried at $120^{\circ} \mathrm{C}$ for $12 \mathrm{~h}$ and then converted into an $\mathrm{H}$-type catalyst by three ion-exchange processes (10 g of sample in $100 \mathrm{~mL}$ of $\left.0.5 \mathrm{M} \mathrm{NH}_{4} \mathrm{NO}_{3}\right)$. $\mathrm{Ni}(4.0$ wt $\%)$ and Mo (12 wt \%) were loaded onto the hierarchical USY by incipient wetness co-impregnation using aqueous $\mathrm{Ni}\left(\mathrm{NO}_{3}\right)_{2}$ and $\left(\mathrm{NH}_{4}\right)_{6} \mathrm{Mo}_{7} \mathrm{O}_{24}$. Then, the samples were stored overnight at room temperature, dried at $120^{\circ} \mathrm{C}$ for $12 \mathrm{~h}$, and calcinated at $550{ }^{\circ} \mathrm{C}$ for $5 \mathrm{~h}$. The obtained catalyst was designated NiMo/SBUY-MCM-41.

NiMo/Al-MCM-41 preparation: The above procedure was repeated without adding USY to obtain MCM-41. Then, $4 \mathrm{~g}$ of the calcinated sample was further modified with $0.68 \mathrm{~g}$ of aluminum isopropoxide in $160 \mathrm{~mL}$ of $0.03 \mathrm{M} \mathrm{HCl}$ solution. The drying, calcination, and Ni/Mo impregnation were performed as above to obtain NiMo/Al-MCM-41.

\subsection{Characterizations}

XRD testing was conducted using a D/MAX-2500 X-ray diffractometer (Tokyo, Japan) with (Cu-K $\alpha$ ) radiation at $40 \mathrm{kV}$ and $140 \mathrm{~mA}$. The zeolites were measured in the $2 \theta$ range from $0^{\circ}$ to $10^{\circ}$ and from $5^{\circ}$ to $60^{\circ}$, respectively.

A chemisorption physisorption analyzer (AMI-300, Altamira Instruments, Pittsburgh, PA, USA) equipped with a thermal conductivity detector (TCD) was used to measure ammonia temperature programmed desorption $\left(\mathrm{NH}_{3}-\mathrm{TPD}\right)$. After pretreatment at $500{ }^{\circ} \mathrm{C}$ in $\mathrm{He}$ for $1 \mathrm{~h}$, the samples were cooled to $80^{\circ} \mathrm{C}$, and $\mathrm{NH}_{3}$ adsorption was then carried out by $\mathrm{NH}_{3}$ in $\mathrm{He}$ at $120^{\circ} \mathrm{C}$ for $30 \mathrm{~min}$. After removing weakly adsorbed $\mathrm{NH}_{3}$ by blowing with $\mathrm{He}$ at $393 \mathrm{~K}$ for $2 \mathrm{~h}$, the $\mathrm{NH}_{3}$-TPD profile was recorded from $120^{\circ} \mathrm{C}$ to $700{ }^{\circ} \mathrm{C}$.

The AMI-300 was also used to conduct $\mathrm{H}_{2}$-TPR experiments. After pretreatment at $450{ }^{\circ} \mathrm{C}$ in He for $1 \mathrm{~h}$, the samples were cooled to ambient temperature before measurement. A mixture of $10 \%$ $\mathrm{H}_{2}+90 \% \mathrm{He}$ was heated at a heating rate of $10{ }^{\circ} \mathrm{C} / \mathrm{min}$ up to $900{ }^{\circ} \mathrm{C}$ in the reduction step. For $\mathrm{CO}$ chemisorption, after being pretreated in helium at $120^{\circ} \mathrm{C}$ for $1 \mathrm{~h}$, the sample $(100 \mathrm{mg})$ was reduced in $\mathrm{H}_{2}$ flow $\left(50 \mathrm{~cm}^{3} / \mathrm{min}\right)$ at $450{ }^{\circ} \mathrm{C}$ for $2 \mathrm{~h}$ and then evacuated at $450{ }^{\circ} \mathrm{C}$ for $2 \mathrm{~h}$. Afterward, the sample was cooled to $40^{\circ} \mathrm{C}$ under vacuum, and then the $\mathrm{CO}$ adsorption isotherm was recorded.

A Bruker Vertex 70 FTIR spectrometer (Karlsruhe, Baden-Württemberg, Germany) with a resolution of $4 \mathrm{~cm}^{-1}$ was used for Py-FTIR measurements. The sample $(10 \mathrm{mg})$ was pretreated under vacuum at $400{ }^{\circ} \mathrm{C}$ for $1 \mathrm{~h}$ and then cooled to $200{ }^{\circ} \mathrm{C}$ to record the background prior to adsorption experiments. Pyridine was injected into the cell and kept for $30 \mathrm{~min}$ in flowing $\mathrm{N}_{2}$. Then, the spectra were recorded between 1300 and $4000 \mathrm{~cm}^{-1}$.

The pore volumes, pore size distribution, and specific surface areas of the samples were measured by $\mathrm{N}_{2}$ adsorption-desorption isotherms on a Micromeritics ASAP-2020 apparatus (Atlanta, GA, USA). Before analysis, all samples were pretreated under vacuum at $300^{\circ} \mathrm{C}$ for $4 \mathrm{~h}$.

\subsection{Hydrotreating of Waste Cooking Oil}

The hydroconversion of WCO was carried out in a fixed-bed flow reactor $(1.2 \mathrm{~cm}$ I.D. and $45 \mathrm{~cm}$ in length). The reaction temperature range (from $340^{\circ} \mathrm{C}$ to $400^{\circ} \mathrm{C}$ ) was dominated by four thermocouples on the reactor wall and controlled by a thermocouple in the catalyst bed. Hydrogen was supplied at a rate that ranged from $12 \mathrm{~L} / \mathrm{h}$ to $36 \mathrm{~L} / \mathrm{h}$ under an experimental pressure range of $2-4 \mathrm{MPa}$. SiC was used to dilute $8 \mathrm{~g}$ of the catalyst to obtain a sufficient catalyst-bed length, and the catalyst was then loaded into the steel reactor. WCO $(20 \mathrm{wt} \%)$ in cyclohexane was used as the feedstock and supplied at a flow rate of $0.8 \mathrm{~mL} / \mathrm{min}$. The $\mathrm{H}_{2} / \mathrm{oil}$ ratio was determined by the hydrogen flow and the total liquid feed flow. The fundamental reactions were conducted at $380^{\circ} \mathrm{C}$ and $3 \mathrm{MPa}$ with an $\mathrm{H}_{2} / \mathrm{oil}$ ratio $(\mathrm{mL} / \mathrm{mL})$ of 500 . The catalysts were presulfided in situ at $320^{\circ} \mathrm{C}$ and $3.0 \mathrm{MPa}$ for $4 \mathrm{~h}$ using $3.0 \mathrm{wt} \%$ $\mathrm{CS}_{2}$ in cyclohexane. 
The products were collected and separated into gaseous products, liquid products (OLPs), and water after the reaction reached stability (at least $5 \mathrm{~h}$ ). The gaseous products were determined with an Agilent Micro 3000 gas chromatograph equipped with three columns (molecular sieve, plot $U$, and alumina) and TCD detectors. The organic liquid products were qualitatively analyzed with an Agilent $6890 \mathrm{~N}$ gas chromatography/5975N mass spectrometry (GC/MS) and quantitatively analyzed using a gas chromatographs (Bruker 456 GC, Bruker, San Francisco, CA, USA) equipped with a flame ionization detector (FID) and a commercial column (ZB-5 HT, $60 \mathrm{~m} \times 0.25 \mathrm{~mm} \times 0.25 \mu \mathrm{m}$ ). The water was weighted. The conversion of $\mathrm{WCO}$ and the selectivity for the formation of hydrocarbons were calculated by Equations (1)-(3):

$$
\begin{aligned}
& \text { Conversion }=100 \% \times\left(\text { Feed }_{\mathrm{G}}-\text { Product }_{\mathrm{G}}\right) / \text { Feed }_{\mathrm{G}} \\
& \text { Selectivity }_{(\mathrm{CxHy})}=(\mathrm{CH})_{\text {nproducts }} / \Sigma(\mathrm{CH})_{\text {nproducts }}
\end{aligned}
$$

Selectivity for the formation of aromatics $=\Sigma(\mathrm{CH})_{\text {aromatics }} / \Sigma(\mathrm{CH})_{\text {nproducts }}$

where Feed ${ }_{\mathrm{G}}$ and products $_{\mathrm{G}}$ represent the weights of $\mathrm{WCO}$ in the feed and the products, respectively; $(\mathrm{CH})_{\text {nproducts }}$ represents the weight of $\mathrm{C}_{\mathrm{n}}$ hydrocarbons in the products.

\section{Conclusions}

The density of strong acid sites and the hydrothermal stability of the SBUY-MCM-41 zeolite assembled with Y building units were higher than those of Al-MCM-41 prepared by postgrafting with aluminum isopropoxide. The micropores of the $Y$ building units were inherited by the SBUY-MCM-41 zeolite, in which a special hierarchical structure was formed and the accessibility of reactants to the micropore active sites was also improved. NiMo/SBUY-MCM-41 significantly enhanced the selective cracking of waste cooking oil for jet-fuel-range hydrocarbons $(37.3 \%)$, with the highest selectivity for the formation of $\mathrm{C}_{10}-\mathrm{C}_{14}$ hydrocarbons and a satisfactory selectivity for the formation of jet-fuel-range aromatics $(7.6 \%)$ as well as a few cyclic compounds. The improved selectivity is the result of the special hierarchical structure and acid distribution of SBUY-MCM-41. Thus, a new strategy is provided to synthesize a hierarchical catalyst for producing alternative jet fuel from WCO.

Author Contributions: All authors conceived and designed the experiments; Z.Z. performed the experiments; Q.W. and X.Z. analyzed the data; Z.Z. wrote the paper.

Funding: This research was funded by the National Natural Science Foundation of China grant number $21476169,21476168$.

Conflicts of Interest: The authors declare no conflicts of interest.

\section{References}

1. Gutiérrez-Antonio, C.; Gómez-Castro, F.I.; de Lira-Flores, J.A.; Hernández, S. A review on the production processes of renewable jet fuel. Renew. Sustain. Energy Rev. 2017, 79, 709-729. [CrossRef]

2. Wang, M.; Chen, M.; Fang, Y.; Tan, T.W. Highly efficient conversion of plant oil to bio-aviation fuel and valuable chemicals by combination of enzymatic transesterification, olefin cross-metathesis, and hydrotreating. Biotechnol. Biofuels 2018, 11, 30. [CrossRef]

3. Yang, J.; Xin, Z.H.; He, Q.; Corscadden, K.; Niu, H. An overview on performance characteristics of bio-jet fuels. Fuel 2019, 237, 916-936.

4. Li, Y.P.; Chen, L.G.; Zhang, Q.H.; Zhang, Q.; Wang, T.J.; Qiu, S.B.; Tan, J.; Li, K.; Ma, L.L. Process and techno-economic analysis of bio-jet fuel-range hydrocarbon production from lignocellulosic biomass via aqueous phase deconstruction and catalytic conversion. Energy Procedia 2017, 105, 675-680. [CrossRef]

5. Ju, C.; Wang, M.; Huang, Y.; Fang, Y.; Tan, T.W. High-quality jet fuel blend production by oxygen-containing terpenoids hydroprocessing. ACS Sustain. Chem. Eng. 2018, 6, 4871-4879. [CrossRef]

6. Zhou, W.J.; Xin, H.; Yang, H.R.; Du, X.Z.; Yang, R.; Li, D.; Hu, C.W. The Deoxygenation Pathways of Palmitic Acid into Hydrocarbons on Silica-Supported $\mathrm{Ni}_{12} \mathrm{P}_{5}$ and $\mathrm{Ni}_{2} \mathrm{P}$ Catalysts. Catalysts 2018, 8, 153. [CrossRef] 
7. Zhang, C.F.; Chen, H.; Zhang, X.W.; Wang, Q.F. TPABr-grafted MWCNT as bifunctional template to synthesize hierarchical ZSM-5 zeolite. Mater. Lett. 2017, 197, 111-114. [CrossRef]

8. Chen, H.; Wang, Q.F.; Zhang, X.W.; Wang, L. Quantitative conversion of triglycerides to hydrocarbons over hierarchical ZSM-5 catalyst. Appl. Catal. B Environ. 2015, 166-167, 327-334. [CrossRef]

9. Li, T.; Cheng, J.; Huang, R.; Zhou, J.; Cen, K. Conversion of waste cooking oil to jet biofuel with nickel-based mesoporous zeolite Y catalys. Bioresour. Technol. 2015, 197, 289-294. [CrossRef]

10. Bezergianni, S.; Voutetakls, S.; Kalogianni, A. Catalytic hydrocracking of fresh and used cooking oil. Ind. Eng. Chem. Res. 2009, 48, 8402-8406. [CrossRef]

11. Talebian-Kiakalaieha, A.; Amina, N.A.S.; Mazaheria, H. A review on novel processes of biodiesel production from waste cooking oil. Appl. Energy 2013, 104, 683-710. [CrossRef]

12. Morais, S.; Mata, T.M.; Martins, A.A.; Pinto, G.A.; Costa, C.A.V. Simulation and life cycle assessment of process design alternatives for biodiesel production from waste vegetable oils. J. Clean. Prod. 2010, 18, 1251-1259. [CrossRef]

13. Verma, D.; Rana, B.S.; Kumar, R.; Sibi, M.G.; Sinha, A.K. Diesel and aviation kerosene with desired aromatics from hydroprocessing of jatropha oil over hydrogenation catalysts supported on hierarchical mesoporous SAPO-11. Appl. Catal. A Gen. 2015, 490, 108-116. [CrossRef]

14. Zhang, Z.Z.; Wang, Q.F.; Chen, H.; Zhang, X.W. Hydroconversion of waste cooking oil into biojet fuel over hierarchical NiMo/USY@Al-SBA-15 zeolite. Chem. Eng. Technol. 2018, 41, 590-597. [CrossRef]

15. Zhang, Z.Z.; Wang, Q.F.; Chen, H.; Zhang, X.W. Hydroconversion of waste cooking oil into green biofuel over hierarchical USY supported NiMo catalyst a comparative study of desilication and dealumination. Catalysts 2017, 7, 281. [CrossRef]

16. Li, P.; Liu, L.P.; Xiong, G. Effect of zeolite precursor on the formation of MCM-41 molecular sieve containing zeolite Y building units. Phys. Chem. Chem. Phys. 2011, 13, 11248-11253. [CrossRef]

17. Li, P.; Xiong, G.; Liu, L.P.; Wang, L.L. Investigation on the effect of zeolite precursor on the formation process of MCM-41 containing zeolite Y building units. Spectrochim. Acta Part A Mol. Biomol. Spectrosc. 2013, 107, 218-226. [CrossRef]

18. Shi, G.; Tan, Q.F.; Liu, H.Y.; Bao, X.J. Templated Assembly of Nano-Crystals of Zeolite Y under Basic Conditions. Chem. React. Eng. Technol. 2013, 29, 470-480.

19. Han, Y.; Wu, S.; Sun, Y.Y.; Li, D.S.; Xiao, F.S. Hydrothermally stable ordered hexagonal mesoporous aluminosilicates assembled from a triblock copolymer and preformed aluminosilicate precursors in strongly acidic media. Chem. Mater. 2002, 14, 1144-1148. [CrossRef]

20. Cordero, R.L.; Agudo, A.L. Effect of water extraction on the surface properties of $\mathrm{Mo} / \mathrm{Al}_{2} \mathrm{O}_{3}$ and $\mathrm{NiMo} / \mathrm{Al}_{2} \mathrm{O}_{3}$ hydrotreating catalysts. Appl. Catal. A Gen. 2000, 202, 23-35. [CrossRef]

21. Solís, D.A.; Agudo, L.; Ramírez, J.; Klimova, T. Hydrodesulfurization of hindered dibenzothiophenes on bifunctional NiMo catalysts supported on zeolite-alumina composites. Catal. Today 2006, 116, 469-477. [CrossRef]

22. Kubička, D.; Horáček, J.; Setnička, M.; Bulánek, R.; Zukal, A.; Kubičková, I. Effect of support-active phase interactions on the catalyst activity and selectivity in deoxygenation of triglycerides. Appl. Catal. B 2014, 145, 101-107. [CrossRef]

23. Chen, H.; Wang, Q.F.; Zhang, X.W.; Wang, L. Hydroconversion of Jatropha Oil to Alternative Fuel over Hierarchical ZSM-5. Ind. Eng. Chem. Res. 2014, 53, 19916-19924. [CrossRef]

24. Mojet, B.L.; Miller, J.T.; Ramaker, D.E.; Koningsberger, D.C. A new model describing the metal-support interaction in noble metal catalysts. J. Catal. 1999, 186, 373-386. [CrossRef]

25. Rajagopal, S.; Marini, H.J.; Marzari, J.A.; Miranda, R. Silica-Alumina-Supported Acidic Molybdenum Catalysts-TPR and XRD Characterization. J. Catal. 1994, 147, 417-428. [CrossRef]

26. Yang, Y.H.; Wang, Q.F.; Zhang, X.W.; Wang, L.; Li, G.Z. Hydrotreating of $\mathrm{C}_{18}$ fatty acids to hydrocarbons on sulphided $\mathrm{NiW} / \mathrm{SiO}_{2}-\mathrm{Al}_{2} \mathrm{O}_{3}$. Fuel Process Technol. 2013, 116, 165-174. [CrossRef]

27. Gong, S.; Shinozaki, A.; Qian, E.W. Role of Support in Hydrotreatment of Jatropha Oil over Sulfided NiMo Catalysts. Ind. Eng. Chem. Res. 2012, 51, 13953-13960. [CrossRef]

28. Zhao, Y.; Liu, Z.; Li, W.; Zhao, Y.; Pan, H.; Liu, Y.; Li, M.; Kong, L. Synthesis, characterization, and catalytic performance of high-silica Y zeolites with different crystallite size. Microporous Mesoporous Mater. 2013, 167, 102-108. [CrossRef] 
29. Adjaye, J.D.; Katikaneni, S.P.R.; Bakhshi, N.N. Catalytic conversion of a biofuel to hydrocarbons: Effect of mixtures of HZSM-5 and silica-alumina catalysts on product distribution. Fuel Process. Technol. 1996, 48, 115-143. [CrossRef]

30. Iliopoulou, E.F.; Heracleous, E.; Delimitis, A.; Lappas, A.A. Producing high quality biofuels: Pt-based hydroisomerization catalysts evaluated using BtL-naphtha surrogates. Appl. Catal. B Environ. 2014, 145, 177-186. [CrossRef]

31. Wang, Y.; Cui, D.M.; Li, Q.Z. Synthesis, characterization and influence parameters on the overgrowth of micro/mesoporous Y-zeolite-MCM-41 composite material under acidic conditions. Microporous Mesoporous Mater. 2011, 142, 503-510. [CrossRef]

(C) 2019 by the authors. Licensee MDPI, Basel, Switzerland. This article is an open access article distributed under the terms and conditions of the Creative Commons Attribution (CC BY) license (http://creativecommons.org/licenses/by/4.0/). 